\title{
ANALISIS KEBUTUHAN PENGEMBANGAN MODEL PEMBELAJARAN PENGETAHUAN MITIGASI BENCANA GEMPABUMI BERBASIS PERMAINAN TRADISIONAL BENGKULU
}

\author{
Panut Setiono $^{*}$, Dwi Anggraini2, Hasnawati ${ }^{3}$ \\ 1,2,3 Program Studi PGSD, Universitas Bengkulu, Bengkulu, Indonesia \\ *Email Koresponden: setiono.pgsd@unib.ac.id \\ Diterima: 17-12-2020, Revisi: 20-05-2021, Disetujui: 09-06-2021 \\ (C)2021 Program Studi Pendidikan Geografi, FISE, Universitas Hamzanwadi
}

\begin{abstract}
Abstrak Pengetahuan mitigasi bencana gempabumi penting dikuasai oleh peserta didik usia sekolah dasar, tujuannya untuk memiminalisir dampak fisik dan psikis ketika gempabumi terjadi. Tujuan dalam penelitian ini adalah untuk mengetahui kebutuhan pengembangan model pembelajaran pengetahuan mitigasi bencana gempa bumi berbasis permainan tradisional Bengkulu. Analisis kebutuhan dalam penelitian ini merupakan bagian proses penelitian dan pengembangan (R\&D) model ADDIE. Analisis kebutuhan dalam penelitian ini dilakukan berdasarkan analisis kurikulum dan analisis karakteristik siswa sebagai pengguna. Pengecekan keabsahan data penelitian dilakukan dengan diskusi teman sejawat. Hasil penelitian yang diperoleh dalam penelitian ini adalah model pembelajaran pengetahuan mitigasi bencana gempabumi berbasis permainan tradisional Bengkulu dapat dilaksanakan di Kelas IV Sekolah Dasar. Tema pembelajaran yang dapat digunakan yaitu Tema Daerah Tempat Tinggalku. Materi pokok yang ditetapkan yaitu: 1) gotong royong, 2) gerak dasar lari, 3) menjaga kelestarian alam, 4) sikap peduli lingkungan, 5) sikap disiplin menjaga kelestarian lingkungan, 6) Membedakan pengetahuan mitigasi bencana masa lampau dan masa sekarang, dan 7) Membuat diagram batang. Hasil analisis kurikulum menunjukkan bahwa model pembelajaran pengetahuan mitigasi bencana gempabumi untuk siswa sekolah dasar dapat dikembangkan.
\end{abstract}

Kata kunci: mitigasi bencana gempabumi, permainan tradisional, pembelajaran tematik terpadu

\begin{abstract}
Earthquake disaster mitigation knowledge is important to be mastered by elementary school students, the aim is to minimize the physical and psychological impacts when an earthquake occurs. The purpose of this study was to determine the analysis of the need for developing a learning model for earthquake mitigation knowledge based on Bengkulu traditional games. The needs analysis in this study is part of the ADDIE model research and development process. The needs analysis in this study was conducted based on curriculum analysis and analysis of student characteristics as users. Checking the validity of research data was carried out by peer discussion. The research results obtained in this study the learning model of earthquake mitigation knowledge learning model based on Bengkulu traditional games can be implemented in 4th Elementary Schools. The learning theme that can be used is the theme of the area where I live. The main materials stipulated are: 1) mutual cooperation, 2) basic running motion, 3) preserving nature, 4) environmental care, 5) discipline attitude to environmental sustainability, 6) distinguishing knowledge of future disaster mitigation past and present, and 7) creating a bar chart. The results of the curriculum analysis show that the earthquake mitigation knowledge learning model for elementary school students can be developed.
\end{abstract}

Keywords: earthquake mitigation, traditional game, thematic learning

\section{PENDAHULUAN}

Provinsi Bengkulu merupakan salah satu wilayah di Indonesia yang termasuk daerah rawan bencana gempabumi. Sebagai daerah yang dilewati jalur gempabumi, Provinsi Bengkulu berada di daerah rawan gempabumi dengan intensitas ringan dan sedang dalam frekuensi kejadian yang cukup tinggi (Supriani, 2009). Dalam periode Agustus 2019 saja setidaknya ada 4 kali gempa bumi yang terjadi dengan kekuatan magnitudo 5,0 (Mongabay, 2019). Sedangkan di tahun 2020 pada tanggal 10 Maret 2020 pukul 21.08.28 WIB gempa juga menggungcang wilayah Bengkulu dengan kekuatan 5,8 magnitudo (Tempo.co, 2020). Gempabumi relatif sering terjadi di Bengkulu, hal ini dikarenakan wilayah 
Provinsi Bengkulu memiliki dua potensi gempabumi, baik darat maupun laut. Di darat berasal dari sesar atau patahan darat aktif, seperti Patahan Manna yang terletak di Kabupaten Bengkulu Selatan, Patahan Musi yang terletak di Kabupaten Kepahiang dan Patahan Ketaun yang terletak di Kabupaten Bengkulu Utara. Sedangkan potensi gempabumi di laut dapat terjadi dari aktivitas Megathrust Mentawai-Pagai, dan Megathrust Enggano (Natawidjaya, 2007).

Gempabumi merupakan rekahan bumi pecah dan bergeser dengan keras yang mengakibatkan getaran asli dari dalam bumi yang merambat ke permukaan bumi (Nur, 2010). Gempabumi juga dapat dikatakan sebagai proses pelepasan sejumlah energi berupa gelombang pada batuan kerak bumi yang menjalar ke segala arah (Gunawan \& Subarjo, 2005). Gempabumi dapat mengakibatkan berbagai kerusakan pada bangunan, juga dapat mengakibatkan tanah longsor, tsunami serta terbelahnya tanah (Sari et al., 2012). Untuk mengurangi risiko dampak kerugian bencana gempabumi perlu dilakukan langkah-langkah strategis dalam memperkecil dan mengurangi dampak kerusakan, baik pada bangunan, kondisi tanah, maupun keselamatan jiwa penduduk yang berada di wilayah bencana (Bakornas PB, 2007). Dampak lainnya yaitu kondisi anak-anak, selain dapat menimbulkan luka fisik juga dapat mengakibatkan trauma atas kejadian yang menimpanya (Winarni \& Purwandari, 2018).

Dari fakta lapangan tersebut, jalur pendidikan dirasa tepat untuk dijadikan sebagai wahana yang efektif untuk menimalkan dampak terjadinya gempabumi (Suarmika \& Utama, 2017), terutama dampak yang mengakibatkan munculnya korban jiwa, salah satunya adalah pendidikan kesiapsiagaan bencana gempabumi menjadi kurikulum yang diintegrasikan dalam pelajaran yang ada di sekolah. Tujuannya agar dampak kerugian yang ditimbulkan dapat diminimalisir sekecil mungkin. Pentingnya peningkatan pemahaman dan ketahanan terhadap bencana itu harus ditanamkan kepada masyarakat sekitar, terutama anak di usia dini yang masih belum mengerti tentang hal-hal apa yang harus mereka lakukan saat peristiwa bencana tidak terduga terjadi (Desfandi, 2014). Khusus untuk siswa di sekolah dasar mitigasi bencana dapat bertujuan salah satunya sebagai pengetahuan dan keterampilan pencegahan bencana baik secara individu maupun masyarakat (Winarni \& Noperman, 2015; Hadi et al., 2019).

Pendidikan mitigasi bencana gempabumi sejauh ini belum terlaksana secara utuh, hal ini terjadi karena pengetahuan mitigasi bencana diberikan kepada siswa sebagai kegiatan pembelajaran muatan lokal serta kegiatan insidental berupa simulasi tanggap bencana gempa bumi melalui program Organisasi Perangkat Daerah (OPD) terkait. Sehingga, integrasi pembelajaran dengan mitigasi bencana alam dengan kurikulum pendidikan belum dapat dilakukan, disebabkan karena kurangnya informasi dan contoh-contoh kegiatan yang berhasil dilaksanakan. Dalam proses pembelajaran di sekolah dasar, kurikulum 2013 diimplementasikan hanya mengikuti tata urutan penyajian yang ada di dalam buku panduan buku guru dan buku siswa yang diterbitkan oleh Kemendikbud yang diperoleh melalui dinas pendidikan. Guru belum mengakomodir potensi lingkungan sekitar sebagai sub-tema pembelajaran, terutama ancamana gempabumi sebagai fokus pengembangan kurikulum dalam penerapan pembelajaran tematik terpadu.

Pendidikan kesiapsiagaan tidak harus menjadi kurikulum tersendiri dan terpisah dengan kurikulum yang sudah ada, tetapi dapat diintegrasikan dalam kurikulum yang berlaku saat ini (Dufty, 2018). Guru harus siap menerapkan materi kebencanaan pada proses pembelajaran (Palupi et al., 2019). Hal ini sesuai semangat impelementasi kurikulum 2013 yang diharapkan mengembangkan tujuan kompetensi yang sesuai dengan karakteristik dan kebutuhan lingkungan sekitar siswa. Menurut (Adiyoso \& Kanegae, 2013) dengan pembelajaran yang mengintegrasikan pendidikan mitigasi bencana dengan implementasi kurikulum 2013 dapat mengembangkan kompetensi sikap spiritual dan sikap sosial yang tinggi. Pendidikan mitigasi bencana juga dapat mengakomodir aspek religius dalam memandang bencana sebagai bentuk ujian atau cobaan dari Tuhan Yang Maha Kuasa, sedangkan pada aspek sosial akan membentuk kepedulian terhadap kelestarian lingkungan dan hubungan sesama manusia.

Agar peserta didik memahami pola penanganan bencana melalui mitigasi bencana alam gempabumi sejak dini, diperlukan kegiatan pembelajaran yang mengintegrasikan kurikulum tematik terpadu dengan pengetahuan mitigasi bencana gempabumi. Tujuannya adalah, agar peserta didik memiliki kepekaan sebagai generasi siaga bencana gempabumi, sehingga mampu meminimalkan potensi resiko yang besar. Penelitian sebelumnya yang dilakukan oleh (Ayub et al., 2019) menyatakan bahwa 
melalui pembelajaran mitigasi bencana gempabumi yang diintegrasikan dengan pendekatan saintifik dapat membuat siswa memahami konsep dampak gempabumi dan langkah-langkah yang dilakukan guna penyelamatan. Siswa juga lebih antusias dan aktif dalam belajar. Demikian juga penelitian (Qurrotaini \& Nuryanto, 2020) mengungkapkan pendidikan mitigasi bencana alam dilaksanakan dalam pembelajaran IPS melalui beberapa tahapan kegiatan yaitu pemberian informasi terjadinya bencana, melindungi diri dengan berlindung ditempat aman, penyelamatan diri keluar ruangan dan berkumpul pada satu titik. Fokus penelitian pendidikan mitigasi bencana alam yang dilakukan oleh (Maknun, 2015) dilakukan pada pembelajaran IPA yang diintegrasikan dengan kearifan lokal berpendekatan Sains, Teknologi, Masyarakat (STM).

Beberapa hasil penelitian di atas belum terlihat pendidikan mitigasi bencana gempabumi dilaksanakan dalam proses pembelajaran di Sekolah Dasar secara utuh, karena penelitian tersebut dilaksanakan pada mata pelajaran tertentu, padahal di Sekolah Dasar sejak tahun 2013 telah menerapkan Kurikulum 2013. Penelitian pendidikan mitigasi bencana gempabumi pada siswa Sekolah Dasar ini dilaksanakan dengan mengintegrasikan permainan Tradisional Bengkulu dalam pembelajaran tematik terpadu. Hal ini sesuai dengan pendapat yang menyatakan bahwa memahami budaya lokal di daerah rawan bencana merupakan alternatif yang sangat masuk akal untuk mengurangi risiko bencana (Suhardjo, 2011; Subagia, 2015). Penggunaan permainan tradisional dalam proses pembelajaran tematik terpadu dapat meningkatkan hasil belajar, aktivitas dan rasa senang siswa dalam belajar. (Indriasari, 2018) juga menyimpulkan terdapat pengaruh positif antara penerapan metode simulasi mitigasi bencana gempabumi terhadap kesiapsiagaan anak menghadapi bencana gempabumi.

Khusus di wilayah Bengkulu, permainan tradisional berkembang berdasarkan penuturan orang terdahulu yang dialaminya pada masa kanak-kanak. Pada umumnya permainan tradisional di Bengkulu ini dapat dikaitkan dengan peristiwa lain yang ada di daerahnya sesuai dengan perkembangan waktu (Lubis \& Chalik, 2013). Misalnya saja, pada masa kerajaan, maka permainan tradisional hanya dapat dilakukan di lingkungan istana kerajaan saja. Lain lagi misalnya, permainan tradisional yang berkembang pada masa penjajahan Inggris maupun Belanda, bentuk permainannya pun juga dapat mengadopsi permainan dari luar yang disesuaikan dengan karakteristik dan kemampuan masyarakat Bengkulu sendiri. Hasil penelitian yang dilakukan oleh Lubis, Chalik, dan Gushevinalti pada tahun 2013 dengan judul Kolaborasi Media Dalam Upaya Pelestarian Permainan Rakyat di Bengkulu melaporkan bahwa, setidaknya ada delapan permainan tradisional Bengkulu yang berasal dari wilayah kabupaten yang ada di Provinsi Bengkulu. Permainan tersebut antara lain: Permainan Sesiku, Permainan Cici Gantung, Permainan Main Tali, Permainan Serebut Benteng, Permainan Batu Limo, Permainan Imeo Kambing, Permainan Gasing, dan Permainan Belacik. Permainan ini dapat dilakukan oleh anak-anak kapanpun, di manapun juga tidak terikat oleh aturan mati. Seluruh kegiatan permainan dilakukan secara sportif berdasarkan kesepakatan para pemainnya.

Tujuan penelitian ini adalah untuk menganalisis pengembangan model pembelajaran pengetahuan mitigasi bencana gempabumi berbasis permainan tradisional Bengkulu yang diintegrasikan dalam pembelajaran tematik terpadu di Sekolah Dasar. Dalam penelitian pengembangan, sebelum produk pembelajaran digunakan langkah yang dilakukan salah satunya adalah melakukan analisis kebutuhan melalui studi literatur (Dadi et al., 2019), yaitu mencermati dan mengembangkan kurikulum yang digunakan di Kelas V Sekolah Dasar.

\section{METODE PENELITIAN}

Penelitian ini merupakan analisis kebutuhan dari penelitian dan pengembangan untuk menghasilkan model pembelajaran pengetahuan mitigasi bencana gempabumi berbasis permainan tradisional Bengkulu untuk siswa Sekolah Dasar. Model pengembangan yang dilakukan yaitu dengan mengikuti langkah-langkah pada model ADDIE atau Analysis-Design-Develop-Implement-Evaluate. Dalam penelitian ini tahapan penelitian dan pengembangan model ADDIE hanya dilakukan pada tahap analysis dan design, hasil penelitian pada pada tahap analysis dan design berupa studi literatur untuk menganalisis kurikulum untuk pengembangan model pembelajaran pengetahuan mitigasi bencana gempabumi berbasis permainan tradisional bengkulu untuk siswa Sekolah Dasar. Sedangkan tahap develop, implement dan evaluate akan dilaksanakan pada tahapan penelitian di tahun berikutnya. 
Data yang dikumpulkan dalam penelitian ini berupa hasil analisis tema pelajaran yang relevan digunakan, hasil analisis pengembangan sub-tema pembelajaran, hasil analisis kesesuaian Kompetensi Dasar yang sesuai dengan Tema dan sub-tema, hasil analisis pengembangan indikator pencapaian kompetensi, hasil analisis pengembangan tujuan pembelajaran, penetapan materi pembelajaran dan penetapan model permainan tradisional yang digunakan. Sumber data dalam penelitian ini diperoleh dari dokumen kurikulum dalam Permendikbud Nomor 20 Tahun 2016 tentang Standar Kompetensi Lulusan Pendidikan Dasar dan Menengah, Permendikbud Nomor 22 Tahun 2016 Tentang Standar Proses Pendidikan Dasar dan Menengah, Peraturan Menteri Pendidikan dan Kebudayaan Nomor 24 tahun 2016 Tentang Kompetensi Inti dan Kompetensi Dasar Pelajaran Pada Kurikulum 2013 Pada Pendidikan Dasar dan Pendidikan Menengah, Buku Tematik Terpadu kelas tinggi Revisi 2017 Terbitan Kemendikbud, dan artikel jurnal yang relevan.

Setelah dilakukan proses pada tahap analysis dan design, maka selanjutnya untuk pengecekan keabsahan data dilakukan dengan diskusi teman sejawat. Tahapan ini dilakukan dengan melakukan diskusi intensif dengan dua orang ahli pengembangan pembelajaran tematik terpadu. Hasil masukkan dari ahli akan digunakan sebagai bahan revisi selanjutnya. Kegiatan ini dilakukan untuk mendapatkan akurasi data hasil studi literatur dan pengembangan kurikulum model pembelajaran pengetahuan mitigasi bencana gempabumi berbasis permainan tradisional bengkulu untuk siswa Sekolah Dasar. Tahapan dan prosedur kegiatan penelitian ini dapat dilihat pada Gambar 1.

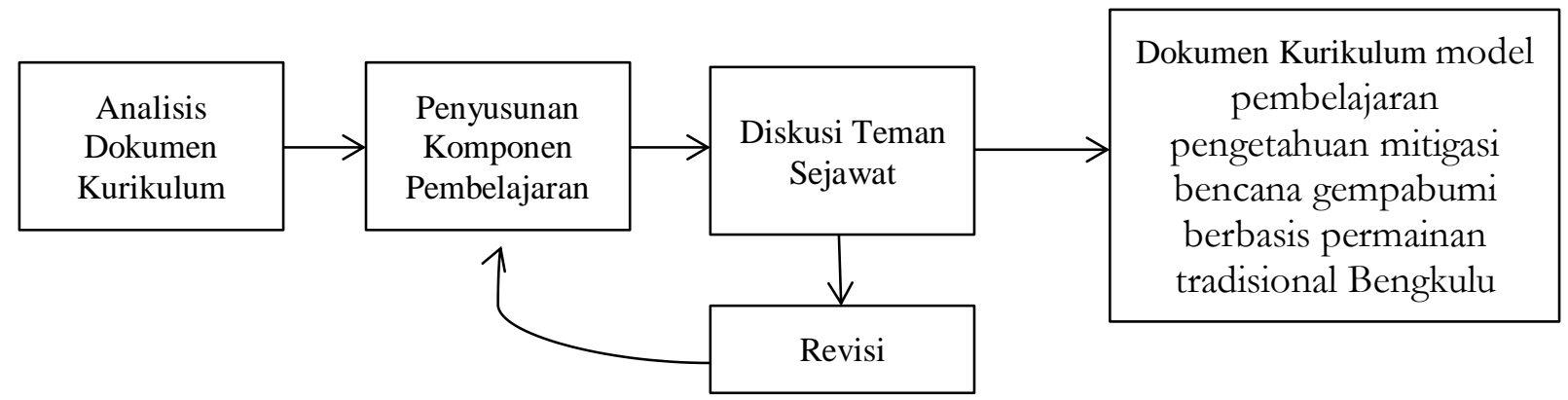

Gambar 1. Prosedur Penelitian

(Sumber : Peneliti, 2021.)

\section{TEMUAN DAN PEMBAHASAN}

Hasil penelitian yang dipaparkan pada bagian ini menyajikan hasil analisis kebutuhan (Analyze) dan pengembangan (Design) yang merupakan bagian dari langkah-langkah penelitian dan pengembangan model ADDIE. Analisis yang dilakukan meliputi analisis karakteristik siswa, analisis pembelajaran dan analisis kurikulum. Pada analisis karakteristik siswa yang dilakukan pada siswa kelas V. Dipilihnya siswa kelas $\mathrm{V}$ sebagai subjek penelitian karena pada usia kelas $\mathrm{V}$ anak dianggap telah memiliki gerak motorik yang sempurna dan memiliki pengetahuan untuk memahami perintah dan petunjuk permainan tradisional. Sebagaimana (Alim, 2009) menyatakan bahwa anak usia Sekolah Dasar dalam kaitannya aktivitas fisik pada umumnya senang bermain, senang bergerak, senang bekerja dalam kelompok juga senang melakukan praktik secara langsung. Selain itu, pada kelas V memungkinkan tema-tema pembelajaran yang akan digunakan dalam pengembangan kurikulum untuk meningkatkan pengetahuan mitigasi bencana alam gempabumi.

Langkah berikutnya adalah melakukan analisis pembelajaran. Pada tahap ini dilakukan pemilihan permainan tradisional Bengkulu yang akan digunakan dalam proses pembelajaran. Permainan Tradisional yang dipilih dalam kegiatan ini yaitu Cici Gandung. Permainan ini lebih mengedepankan kekuatan otot motorik anak yang dibutuhkan dalam upaya penyelamatan diri dalam proses pembelajaran mitigasi bencana alam, selain itu permainan ini juga kaya dengan pembelajaran yang mengasah kemampuan intelektual peserta didik untuk mengambil keputusan secara cepat dan tepat. Anak usia Sekolah Dasar mengerahkan seluruh energinya untuk menguasai keterampilan intelektual dan pengetahuannya. Untuk ini permainan tradisional dapat digunakan sebagai media untuk menyalurkan energi anak tersebut. (King, 2013 dalam Suryana \& Indrawati, 2018). 
Analisis kebutuhan selanjutnya adalah melakukan analisis kurikulum (Nurjannah, 2018). Dengan analisis ini, dapat diketahui kebutuhan yang akan digunakan untuk intervensi serta menentukan kesenjangan dan faktor penyebabnya (Puspitasari, 2013). Hasil analisis kurikulum yang telah dilakukan akan menghasilkan tema, subtema dan kompetensi dasar yang sesuai untuk digunakan dalam pengembangan model pembelajaran pengetahuan mitigasi bencana gempabumi berbasis permainan tradisional Bengkulu untuk siswa Sekolah Dasar. Dari identifikasi yang dilakukan, tema-tema yang berpotensi dapat diintegrasikan dalam pembelajaran ini, yaitu: 1) Tema di kelas IV: Indahnya kebersamaan, Indahnya keragaman negeriku, dan Daerah Tempat Tinggalku; 2) Tema Kelas V: Gerak Hewan dan Manusia, peristiwa dalam kehidupan, dan lingkungan sahabat kita; dan 3) Kelas VI: Bumiku dan Persatuan dalam perbedaan.

Dalam penelitian ini, tema pembelajaran yang akan dikembangkan dalam pembelajaran mitigasi bencana gempabumi berbasis permainan tradisional akan dilaksanakan pada tema Daerah Tempat Tinggalku. Setelah tema ditetapkan, selanjutnya dilakukan pemetaan sub-tema yang terkait dengan tema untuk digunakan dalam pembelajaran. Berikut ini disajikan sub-tema pembelajaran dari tema Daerah Tempat Tinggalku (Gambar 2).

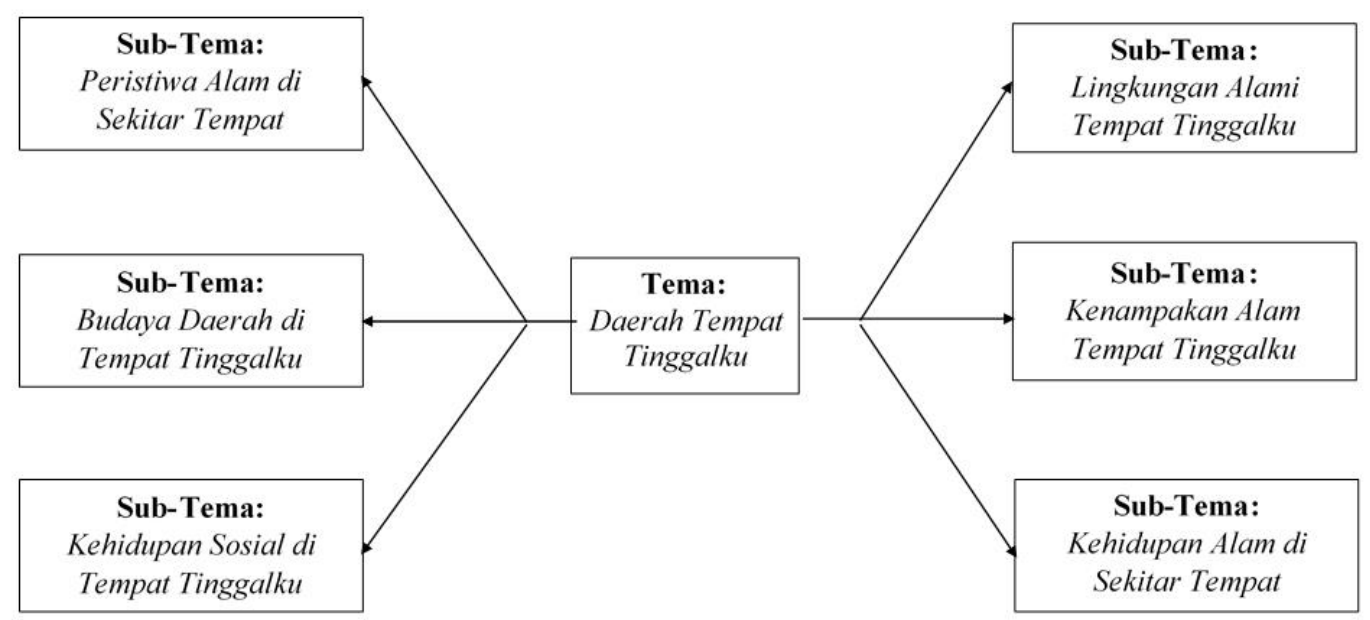

Gambar 2. Jaring-jaring Sub-tema

(Sumber: Peneliti, 2021)

Dari Gambar 2 dapat diketahui bahwa tema Daerah Tempat Tinggalku dapat dikembangkan menjadi enam sub-tema, yaitu: 1) Peristiwa Alam di Sekitar Tempat Tinggalku; 2) Budaya Daerah di Tempat Tinggalku; 3) Kehidupan Sosial di Tempat Tinggalku; 4) Kenampakan Alam Tempat Tinggalku; 5) Lingkungan Alami Tempat Tinggalku; dan 6) Kehidupan Alam di Sekitar Tempat Tinggal. Sub-tema yang dikembangkan di atas, berbeda dengan subtema yang telah digunakan oleh satuan pendidikan yang tercantum dalam Buku Guru dan Buku Siswa, hal ini bertujuan agar pembelajaran tematik yang akan dilakukan bermakna dan sesuai dengan lingkungan belajar peserta didik (Faris \& Lestari, 2016) yang berada di wilayah rawan bencana gempabumi. Demikian juga (Maryatun, 2017) menyatakan bahwa pengembangan tema hendaknya disesuaikan dengan latar belakang kehidupan anak dan sumber daya yang tersedia.

Setelah sub-tema ditetapkan, selanjutnya dilakukan analisis kesesuaian Kompetensi Dasar, Indikator Pencapaian Kompetensi, dan Tujuan Pembelajaran. Hal ini bertujuan untuk mengetahui lebih lanjut tingkat kesesuaian Kompetensi Dasar, Indikator Pencapaian Kompetensi, dan Tujuan Pembelajaran dalam rangka mendapatkan dokumen perancanaan kurikulum pembelajaran yang tepat dan efektif. Analisis Kompetensi Dasar didasarkan pada Peraturan Menteri Pendidikan dan Kebudayaan Nomor 24 Tahun 2016 tentang struktur kurikulum pendidikan dasar dan menengah. Hasil analisis yang telah dilakukan dapat dilihat pada Tabel 1. 
Tabel 1. Pemetaan Tema, Sub-Tema, dan Kompetensi Dasar

\begin{tabular}{|c|c|c|c|}
\hline No. & Tema & Sub-Tema & Kompetensi Dasar \\
\hline 1 & $\begin{array}{l}\text { Daerah } \\
\text { Tempat } \\
\text { Tinggalku }\end{array}$ & $\begin{array}{l}\text { Lingkungan Alami } \\
\text { Tempat Tinggalku }\end{array}$ & $\begin{array}{l}\text { Bahasa Indonesia: } \\
\text { 3.10 Membanding-kan watak setiap tokoh pada teks fiksi } \\
\text { 4.10 Menyajikan hasil membanding-kan watak setiap tokoh pada teks } \\
\text { fiksi secara lisan, tulis, dan visual. } \\
\text { IPS: } \\
\text { 3.2 Mengidentifikasi keragaman sosial, ekonomi, budaya, etnis, dan } \\
\text { agama di provinsi setempat sebagai identitas bangsa Indonesia; serta } \\
\text { hubungannya dengan karakteristik ruang. } \\
\text { 4.2 Menyajikan hasil identifikasi mengenai keragaman sosial, ekonomi, } \\
\text { budaya, etnis, dan agama di provinsi setempat sebagai identitas bangsa } \\
\text { Indonesia; serta hubungannya dengan karakteristik ruang. } \\
\text { IPA: } \\
\text { 3.8 Menjelaskan pentingnya upaya keseimbangan dan pelestarian sumber } \\
\text { daya alam di lingkungannya. } \\
\text { 4.8 Melakukan kegiatan upaya pelestarian sumber daya alam bersama } \\
\text { orang-orang di lingkungannya } \\
\text { PPKn: } \\
\text { 1.2 Menghargai kewajiban dan hak warga masyarakat dalam kehidupan } \\
\text { sehari-hari dalam menjalankan agama } \\
\text { 2.2 Menunjukkan sikap disiplin dalam memenuhi kewajiban dan hak } \\
\text { sebagai warga masyarakat sebagai wujud cinta tanah air } \\
\text { 3.2 Mengidentifikasi pelaksanaan kewajiban dan hak sebagai warga } \\
\text { masyarakat dalam kehidupan sehari-hari. } \\
\text { 4.2 Menyajikan hasil identifikasi pelaksanaan kewajiban dan hak sebagai } \\
\text { warga masyarakat dalam kehidupan sehari-hari. } \\
\text { Matematika: } \\
\text { 3.11 Menjelaskan data diri peserta didik dan lingkungannya yang disajikan } \\
\text { dalam bentuk diagram batang. } \\
\text { 4.11 Mengumpulkan data diri peserta didik dan lingkungannya dan } \\
\text { menyajikan dalam bentuk diagram batang } \\
\text { 3.3 Memahami variasi gerak dasar jalan, lari, lompat, dan lempar melalui } \\
\text { permainan/olahraga yang dimodifikasi dan atau olahraga tradisional } \\
4.3 \text { Mempraktikkan variasi pola dasar jalan, lari, lompat, dan lempar } \\
\text { melalui permainan/olahraga yang dimodifikasi dan atau olahraga } \\
\text { tradisional }\end{array}$ \\
\hline
\end{tabular}

Sumber: Analisis Peneliti, 2021.

Berdasarkan Tabel 1, maka dapat dilihat bahwa pada kompetensi dasar yang sesuai dengan subtema Lingkungan Alami Tempat Tinggalku terdapat pada muatan pembelajaran Bahasa Indonesia, Pendidikan Pancasila dan Kewarganegaraan, Ilmu Pengetahuan Alam, Matematika dan Ilmu Pengetahuan Sosial. Setelah penetapan Kompetensi Dasar yang sesuai, selanjutnya dilakukan pengembangan Indikator dan Tujuan pencapaian Kompetensi sesuai dengan tingkat pencapaian komepetensi yang akan dicapai. Sajian analisis hasil pengembangan KD menjadi indikator dan tujuan pembelajaran dapat dilihat pada Tabel 2 .

Tabel 2. Analisis Pengembangan KD Menjadi Indikator dan Tujuan pembelajaran

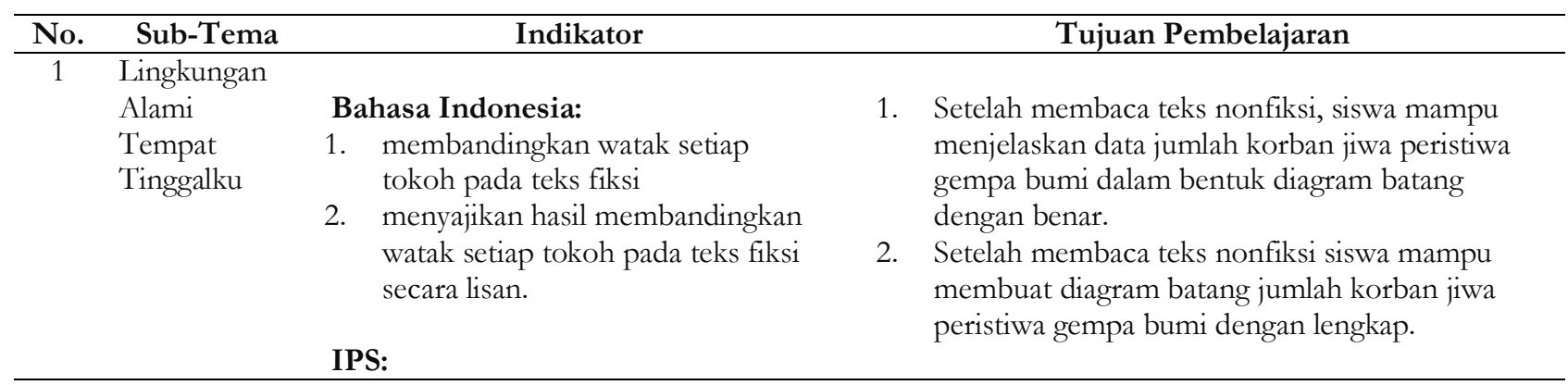




\begin{tabular}{|c|c|c|c|}
\hline \multirow{10}{*}{\multicolumn{2}{|c|}{ sub-1 ema }} & \begin{tabular}{|l} 
Indikator \\
\end{tabular} & $\begin{array}{c}\text { Tujuan Pembelajaran } \\
\end{array}$ \\
\hline & & $\begin{array}{l}\text { 3. Mengidentifikasi kehidupan sosial } \\
\text { yang sesuai dengan karakteristik } \\
\text { ruang. } \\
\text { menyajikan hasil identifikasi } \\
\text { kehidupan sosial yang sesuai } \\
\text { dengan karakteristik ruang di } \\
\text { Provinsi Bengkulu. }\end{array}$ & $\begin{array}{l}\text { 3. Setelah melihat tayangan video pembelajaran } \\
\text { Kegiatan Gotog Royong, siswa mampu } \\
\text { memberikan pendapatnya tentang manfaat } \\
\text { gotong royong dengan benar } \\
\text { 4. Setelah melihat tayangan video pembelajaran } \\
\text { tentang kegiatan pembelajaran, siswa mampu } \\
\text { membuat peta konsep manfaat gotong royong } \\
\text { dengan benar. }\end{array}$ \\
\hline & & $\begin{array}{l}\text { IPA: } \\
\text { 5. Menjelaskan pentingnya upaya } \\
\text { menjaga pelestarian alam sumber } \\
\text { daya alam di Provinsi bengkulu } \\
\text { 6. Melakukan kegiatan pelestarian } \\
\text { lingkungan bersama teman di kelas. }\end{array}$ & $\begin{array}{l}\text { 5. Setelah bermain cici gandung, siswa mampu } \\
\text { menjelaskan pentingnya menjaga kelestarian alam } \\
\text { di wilayahnya dengan benar. } \\
\text { 6. Setelah bermain cici gandung, siswa mampu } \\
\text { melakukan kegiatan pelestarian alam di } \\
\text { wilayahnya dengan benar. }\end{array}$ \\
\hline & & PPKn: & \\
\hline & & $\begin{array}{l}\text { 7. Menunjukkan sikap peduli } \\
\text { lingkungan. }\end{array}$ & $\begin{array}{l}\text { 7. Setelah bermain cici gantung, siswa mampu } \\
\text { menunjukkan sikap peduli lingkungan dengan } \\
\text { membersihkan lapangan bermain yang digunakan }\end{array}$ \\
\hline & & $\begin{array}{l}\text { 8. Menunjukkan sikap peduli } \\
\text { lingkungan }\end{array}$ & $\begin{array}{l}\text { 8. Setelah bermain cici gantung siswa mampu } \\
\text { menunjukkan sikap disiplin dalam membersihkan } \\
\text { lapangan bermain yang digunakan. }\end{array}$ \\
\hline & & 9. Melestarikan lingkungan Alami & $\begin{array}{l}\text { 9. Setelah bermain cici gantung, siswa mampu } \\
\text { menjelaskan perilaku yang dapat melestarikan } \\
\text { alam dengan benar. }\end{array}$ \\
\hline & & $\begin{array}{l}\text { 10. Menyajikan hasil identifikasi } \\
\text { kegiatan pelestarian lingkungan } \\
\text { alami. }\end{array}$ & $\begin{array}{l}\text { 10. Setelah bermain cici gantung siswa mampu } \\
\text { membuat tabel hasil identfikasi perilaku } \\
\text { melestarikan alam lingkungan. }\end{array}$ \\
\hline & & $\begin{array}{l}\text { Matematika: } \\
\text { 11. Menjelaskan jumlah penduduk } \\
\text { yang disajikan dalam bentuk } \\
\text { diagram batang. } \\
\text { 12. Mengumpulkan data jumlah } \\
\text { penduduk dan menyajikannya } \\
\text { dalam bentuk diagram batang. }\end{array}$ & $\begin{array}{l}\text { 11. Setelah membaca teks nonfiksi, siswa mampu } \\
\text { menjelaskan data jumlah korban jiwa peristiwa } \\
\text { gempa bumi dalam bentuk diagram batang } \\
\text { dengan benar. } \\
\text { 12. Setelah membaca teks nonfiksi siswa mampu } \\
\text { membuat diagram batang jumlah korban jiwa } \\
\text { peristiwa gempa bumi dengan lengkap. }\end{array}$ \\
\hline & & $\begin{array}{l}\text { Penjasorkes: } \\
\text { 13. Memahami gerak dasar lari melalui } \\
\text { permainan Cici Gandung } \\
\text { 14. Mempraktikkan variasi pola dasar } \\
\text { lari melalui permainan Cici } \\
\text { Gandung. }\end{array}$ & $\begin{array}{l}\text { 13. Setelah bermain cici gandung, siswa mampu } \\
\text { memahami gerak dasar lari melalui permainan } \\
\text { cici gandung dengan benar. } \\
\text { 14. Setelah bermain cici gandung, siswa mampu } \\
\text { mempraktikkan variasi pola dasar lari dengan } \\
\text { tepat. }\end{array}$ \\
\hline
\end{tabular}

Sumber: Analisis Peneliti, 2021.

Tahap berikutnya menetapkan pokok yang akan disajikan dalam komponen perangkat pembelajaran yang dikembangkan. Dalam penelitian materi pokok yang ditetapkan yaitu: 1) gotong royong; 2) gerak dasar lari; 3) menjaga kelestarian alam; 4) sikap peduli lingkungan; 5) sikap disiplin menjaga kelestarian lingkungan; 6) membedakan pengetahuan mitigasi bencana masa lampau dan masa sekarang; dan 7) membuat diagram batang. Sedangkan media pembelajaran yang digunakan untuk mencapai tujuan kompetensi yang telah dikembangkan yaitu Lembar Kegiatan Peserta Didik, video pembelajaran, dan teks bacaan. Metode pembelajaran yang dilakukan dalam kegiatan pembelajaran ini dengan cara ceramah, diskusi kelompok, demonstrasi, melakukan permainan tradisional, tanya jawab, dan penugasan individu. Penggunaan strategi pembelajaran yang bervariasi dapat meningkaykan motivasi belajar peserta didik (Tahir \& Elihami, 2020).

Setelah analisis kurikulum dilakukan, tahap berikutnya adalah mengembangkan buku panduan guru. Tujuannya untuk memudahkan guru dalam melaksanakan kegiatan pembelajaran mitigasi bencana 
alam gempabumi berbasis permainan tradisional yang diintegrasikan dalam kegiatan pembelajaran tematik terpadu. Buku panduan ini disusun untuk dua kali kegiatan pembelajaran. Kegiatan pembelajaran ini disusun sesuai dengan unsur komponen dalam silabus dan Rencana Pelaksanaan Pembelajaran dalam Peraturan Menteri Pendidikan dan Kebudayaan Nomor 22 Tahun 2016 Tentang Standar Proses. Hal ini bertujuan, agar model pembelajaran dikembangkan sesuai dengan tuntutan kurikulum pendidikan ditingkat sekolah dasar.

Rancangan kegiatan pembelajaran mitigasi bencana gempabumi berbasis permainan tradisional dilaksanakan dengan langkah-langkah sebagai berikut: 1) guru membuka pelajaran, melakukan apersepsi dan menyampaikan tujuan pembelajaran; 2) guru memberikan teks dan menayangkan video pembelajaran sesuai dengan materi; 3) guru mempersiapkan siswa untuk bermain Cici Gandung dan membagi siswa menjadi beberapa kelompok dengan anggota sebanyak 4 orang; 4) siswa memilih peran masing-masing dalam kelompok sesuai dengan peran dalam permainan Cici Gandung, yaitu dua orang sebagai penopang, 1 orang yang naik ditangan temannya, dan 1 orang sebagai pembantu kelompok; 5) Tata cara pembagian peran masing-masing kelompok dilakukan dengan dua cara, yaitu: ansum dan cai-cai geruai; 6) siswa mempresentasikan hasil kerja kelompok dengan permainan cici gandung, kemudian ditentukan pemenangnya; 7) siswa bersama guru menyimpulkan materi yang telah dipelajari; dan 8) guru menutup pelajaran.

Setelah proses pengembangan selesai dilakukan, langkah berikutnya adalah pengemasan produk pengembangan berupa buku panduan model pembelajaran mitigasi bencana gempabumi berbasis permainan tradisional untuk digunakan pada proses pembelajaran tematik terpadu. Rancangan model pembelajaran mitigasi bencana gempabumi berbasis permainan tradisional ini secara umum dapat digunakan sebagai proses pembelajaran yang menjunjung tinggi penghargaan pada budaya lokal. Hal ini disebkan karena pembelajaran dengan budaya lokal dapat mewujudkan pembelajaran menyenangkan sehingga perendaman otak memproses materi menuju respon kognitif yang memadai, serta cinta dengan budaya bangsa.

\section{SIMPULAN}

Dari tahap analisis kurikulum yang dilakukan dalam rancangan model pembelajaran mitigasi bencana gempa bumi berbasis permainan tradisional Bengkulu yang diintegrasikan dalam pembelajaran tematik terpadu untuk siswa Sekolah Dasar dapat simpulkan bahwa tema yang sesuai digunakan dalam pembelajaran ini yaitu Daerah Tempat Tinggalku. Setelah tema ditetapkan, selanjutnya dikembangkan menjadi subtema, yaitu Peristiwa Alam di Sekitar Tempat Tinggalku, Budaya Daerah di Tempat Tinggalku, Kehidupan Sosial di Tempat Tinggalku, Lingkungan Alami Tempat Tinggalku, Kenampakan Alam Tempat Tinggalku, Kehidupan Alam di Sekitar Tempat Tinggalku. Kompetensi Dasar yang sesuai digunakan dalam model pembelajaran ini yaitu Kompetensi Dasar dari muatan pembelajaran Ilmu Pengetahuan Sosial, Ilmu Pengetahuan Alam, Bahasa Indonesia, Matematika, Pendidikan Pancasila dan Kewarganegaraan, Pendidikan Jasmani dan Kesehatan serta Seni Budaya dan Prakarya. Untuk memudahkan guru melaksanakan kegiatan pembelajaran, disajikan dalam Buku Panduan yang disesuaikan dengan Peraturan Menteri Pendidikan dan Kebudayaan Nomor 22 Tahun 2016 Tentang Standar Proses. Implementasi model pembelajaran dilaksanakan dengan mengembangkan Rencana Pelaksanaan Pembelajaran (RPP).

\section{UCAPAN TERIMA KASIH}

Ucapan terima kasih disampaikan kepada Lembaga Penelitian dan Pengabdian Pada Masyarakat Universitas Bengkulu yang telah menyediakan dana untuk kegiatan penelitian dan pengembangan ini pada pendanaan kegiatan Tahun 2020.

\section{DAFTAR PUSTAKA}

Adiyoso, W., \& Kanegae, H. (2013). Efektifitas Dampak Penerapan Pendidikan Kebencanaan di Sekolah Terhadap Kesiapsiagaan Siswa Menghadapi Bencana Tsunami di Aceh. Indonesia. Indonesia. Majalah. indd Spread, 23.

Alim, A. (2009). Permainan Mini Tenis untuk Pembelajaran di Siswa Sekolah Dasar. Jurnal Pendidikan Jasmani Indonesia, 6(2), 61-66. 
Ayub, S., Kosim, K., Gunada, I. W., \& Zuhdi, M. (2019). Model Pembelajaran Kesiapsiagaan Bencana Gempabumi di Sekolah Dasar. ORBITA: Jurnal Kajian, Inovasi dan Aplikasi Pendidikan Fisika, 5(2), 65.

Bakornas, P. B. (2007). Pengenalan Karakteristik Bencana dan Upaya Mitigasinya di Indonesia. Jakarta. Direktorat Mitigasi.

Dadi, I. K., Redhana, I. W., \& Juniartina, P. P. (2019). Analisis Kebutuhan untuk Pengembangan Media Pembelajaran IPA Berbasis Mind Mapping. Jurnal Pendidikan Dan Pembelajaran Sains Indonesia (JPPSI), 2(2), 70.

Desfandi, M. (2014). Urgensi Kurikulum Pendidikan Kebencanaan Berbasis Kearifan Lokal di Indonesia [The Urgency of Disaster Education Curriculum Based on Local Wisdom in Indonesia\}. Sosio Didaktika Sosial Science Education Journal, 1(2), 191-198.

Dufty, N. (2018). A New Approach to Disaster Education. The International Emergency Management Society (TIEMS) Annual Conference, Manila, Philippines, 13-16, November, 1-10.

Faris, A., \& Lestari, A. F. (2016). Pengembangan Tema dalam Pembelajaran Anak Usia Dini. Teknike Komputer, 2(1), 59-67.

Gunawan, \& Subarjo. (2005). Pengantar Seismologi. Jakarta: Badan Meteorologi dan Geofisika.

Hadi, H., Agustina, S., \& Subhani, A. (2019). Penguatan Kesiapsiagaan Stakeholder dalam Pengurangan Risiko Bencana Alam Gempabumi. Geodika: Jumal Kajian Ilmu dan Pendidikan Geografi, 3(1), 30.

Indriasari, F. N. (2018). Pengaruh Pemberian Metode Simulasi Siaga Bencana Gempa Bumi terhadap Kesiapsiagaan Anak di Yogyakarta. Jurnal Keperawatan Soedirman, 11(3), 199.

Lubis, B., \& Chalik, A.A., Gushevinalti (2013). Laporan Penelitian Hibah Bersaing Kolaborasi Media Dalam Upaya Pelestarian Permainan Rakyat Di Bengkulu.

Maknun, J. (2015). Pembelajaran Mitigasi Bencana Berorientasi Kearifan Lokal Pada Pembelajaran IPA di Sekolah Menengah Kejuruan. Jurnal Kajian Pendidikan, 5(1), 143-156.

Maryatun, I. B. (2017). Pengembangan Tema Pembelajaran untuk Taman Kanak-kanak. Jurnal Pendidikan Anak, 6(1), 41-47.

Mongabay. (2019). Bengkulu Harus Siap, Hadapi Potensi Bencana. Diakses pada 25 Mei 2021 dari https://www.mongabay.co.id/2019/08/26/bengkulu-harus-siap-hadapi-potensi-bencana/.

Natawidjaja, D. H. (2007). Gempabumi dan Tsunami di Sumatra dan Upaya untuk Mengembangkan Lingkungan Hidup yang Aman dari Bencana Alam. Laporan KHL, LIPI, Jakarta.

Nur, A. M. (2010). Gempa Bumi, Tsunami dan Mitigasinya. Jurnal Geografi: Media Informasi Pengembangan dan Profesi Kegeografian, 7(1), 66-73.

Nurjannah, N. (2018). Analisa Kebutuhan Sebagai Konsep Dasar dalam Pengembangan Kurikulum Bahasa Arab di MAN Curup. Arabiyatuna: Jurnal Babasa Arab, 2(1), 49.

Palupi, H. S., Masution, M. W., Rida, P. A., \& Meliyani, M. (2019). Analisis Tingkat Kesiapan Guru dalam Menerapkan Materi Kebencanaan Pada Proses Pembelajaran di Kabupaten Klaten. Geodika: Jurnal Kajian Ilmu Dan Pendidikan Geografi, 3(2), 48.

Puspitasari, C. D. (2013). Analisis Kebutuhan untuk Meningkatkan Kemampuan Tenaga Kependidikan dalam Menerapkan Penguasaan Pribadi. Perspektif Imu Pendidikan, 27(1), 69-79.

Qurrotaini, L., \& Nuryanto, N. (2020). Implementasi Pendidikan Mitigasi Bencana Alam Gempa Bumi Dalam Pembelajaran IPS SD. Trapsila: Jurnal Pendidikan Dasar, 2(1), 37-44.

Sari, A. W., Jasruddin, \& Ihsan, N. (2012). Analisis Rekahan Gempa Bumi dan Gempa Bumi Susulan dengan Menggunakan Metode Omori. Sains dan Pendidikan Fisika, 8(3), 263-268. 
Suarmika, P. E., \& Utama, E. G. (2017). Pendidikan Mitigasi Bencana di Sekolah Dasar (Sebuah Kajian Analisis Etnopedagogi). JPDI (Jurnal Pendidikan Dasar Indonesia), 2(2), 18.

Subagia, I. W. (2015). Pelatihan Mitigasi Bencana Alam Gempa Bumi Pada Siswa Sekolah Dasar Negeri 1 Pengastulan Kecamatan Seririt Kabupaten Buleleng Bali. JPI (Jurnal Pendidikan Indonesia), 4(1).

Suhardjo, D. (2011). Arti Penting Pendidikan Mitigasi Bencana dalam Mengurangi Risiko Bencana. Jurnal Cakrawala Pendidikan, (2).

Supriani, F. (2009). Studi Mitigasi Gempa di Bengkulu dengan Membangun Rumah Tahan Gempa. Inersia: Jurnal Teknik Sipil, 1(1), 8-15.

Suryana, N. M., \& Indrawati, D. (2018). Pengembangan Media Pembelajaran Berbasis Permainan Tradisional "Gaprek Kaleng" untuk Menanamkan Konsep Pecahan Siswa Kelas III SD. Jurnal Penelitian Pendidikan Guru Sekolab Dasar, 6(3).

Tahir, M., \& Elihami, E. (2020). Peningkatan Variasi Mengajar Pada Proses Pembelajaran Mahasiswa Semester Tiga di Prodi Pendidikan Nonformal STKIP Muhammadiyah Enrekang. Jurnal Edukasi Nonformal, 1(1), 201-209.

Tempo.co (2020). Gempa 5,8 M Guncang Wilayah Bengkulu Malam Ini. Diakses pada 25 Mei 2021 dari https://tekno.tempo.co/read/1318015/gempa-58-m-guncang-wilayah-bengkulu-malam-ini.

Winarni, E. W., \& Noperman, F. (2015). Identifikasi Kompetensi Dasar dan Indikator Program Pengurangan Risiko Bencana Gempa Bumi Terintegrasi Dalam Pembelajaran Tematik Terpadu di Sekolah Dasar Kota Bengkulu. Proceeding “6th Pedagogy International Seminar 2015” ISBN 978-9793786-50-6 Jilid II, 425-829.

Winarni, E. W., \& Purwandari, E. P. (2018). Disaster Risk Reduction for Earthquake Using Mobile Learning Application to Improve the Students Understanding in Elementary School. Mediterranean Journal of Social Sciences, 9(2), 205-214. 